\title{
The Indonesian Constitutional Court: Reconfiguring Decentralization for Better or Worse?
}

\author{
Simon BUTT* \\ University of Sydney Law School, Australia \\ simon.butt@sydney.edu.au
}

\begin{abstract}
After Soeharto stepped down in 1998, Indonesia began a radical decentralization program, one aspect of which was granting wide-ranging lawmaking powers to subnational governments. The national legislation establishing the decentralization framework gave power to the central government to review provincial-level laws, and, from $20 \mathrm{I}_{4}$, for provincial governors to review city and county laws, and to invalidate them if they are inconsistent with national laws, morality, or public order. In 2017, the Constitutional Court declared these review mechanisms unconstitutional, deciding that these reviews should be conducted by the Supreme Court rather than the national or provincial executive governments. This decision reversed the trend of successive reforms from 2004 that had begun restoring political and legal power to the centre. It was also one of the most problematic in the Court's history, as this article demonstrates. The legal reasoning was poor and incomplete, the Court appeared to be equally split (though the Court did not acknowledge this), and the consequences of the decision (which the Court did not appear to consider) are likely dire. The decision has caused great confusion, but despite its flaws may well lead to reforms requiring the Constitutional Court, rather than the Supreme Court, to review subnational laws.
\end{abstract}

When Indonesia decentralized rapidly after the fall of Soeharto in I998, many of its subnational governments were unprepared for their much-expanded responsibilities. Indonesia had just emerged from four decades of authoritarian rule under which local governments had been responsible for implementing the central government's policies, rather than developing their own and converting them into law. Anticipating that these subnational governments might need help and oversight - and sometimes even to be reined in - Indonesia's decentralization statutes of 1999, 2004, and 2014 included provisions requiring subnational governments to send their laws, once enacted, to the central government for review. ${ }^{\mathrm{I}}$ Under Law No 23 of 2014 on Regional Government

\footnotetext{
* Professor of Indonesian Law, University of Sydney Law School.

I. The first statutory bases for these reforms were Law No 22 of 1999 on Regional Government and Law No 25 of 1999 on Fiscal Balance between the Central and Regional Governments. The former was
} 
(20I4 Regional Government Law), the Ministry of Home Affairs was empowered to review provincial laws, and power was delegated to provincial governors to review city and county laws. ${ }^{2}$ Under these provisions, the Ministry and governor could invalidate subnational laws by issuing a formal decision. ${ }^{3}$ Using these powers, the Ministry revoked several thousand subnational laws, mostly for imposing illegal taxes and fees. ${ }^{4}$

In 2017, the Indonesian Constitutional Court issued two of the most problematic and potentially far-reaching decisions of its fourteen year history: the Perda Review cases. ${ }^{5}$ In them, the Court invalidated the provisions of Indonesia's 20I4 Regional Government Law, under which the central and provincial governments had reviewed and invalidated subnational laws. These decisions went against the legislative trend to increase central government authority at the expense of local governments. ${ }^{6}$

These Constitutional Court decisions have very little to commend them for four main reasons that I explore in this article. First, the Court's reasoning was deeply flawed, as I discuss in Part III. The decisions contain many contentious - perhaps even erroneous - assertions about Indonesian law, and the judges did not adequately explain how they reached their conclusions. The decisions were also a missed opportunity for the Court to clarify uncertainties about the operation of the main ordering principles of the Indonesian legal system: the so-called 'hierarchy of laws'. With these decisions, the Court may have even worsened this uncertainty, which has persisted for decades in Indonesia and substantially contributes to the system's dysfunction.

Second, the Court's decision-making processes were seriously defective, as I explain in Part IV. In these cases, the judicial panel was evenly split, either during hearings or when the decisions were made. The Court did not acknowledge this, let alone justify it. Why the 'majority' decisions were adopted as 'the decision' of the Court in these cases is by no means clear, given that an equal number of judges dissented.

Third, as I explore in Part V, the majority did not demonstrate that it considered two important consequences of its decisions. The first is that the national and provincial governments had been able to curb at least some of the exploitative over-regulation of subnational governments. They had culled several thousand regional regulations, even though the review processes that they employed were deeply flawed. The second consequence is relying exclusively on the Supreme Court to review subnational laws. The Supreme Court has a poor record of judicial review, including in cases involving review of subnational laws. In any case, judicial review does not appear to be an

replaced by Law No 32 of 2004 on Regional Government, which itself was then replaced by Law No 23 of 2014 on Regional Government.

2. 2014 Regional Government Law, arts 249-250.

3. 2014 Regional Government Law, art $25 \mathrm{I}$.

4. Ayomi Amindoni, 'Government Annuls 3,I43 Bylaws' The Jakarta Post (Jakarta, I3 June 2016) < www. thejakartapost.com/news/20I6/06/I3/government-annuls-3 I43-bylaws.html > accessed 6 October 2018.

5. Constitutional Court of Indonesia, Decision No I37/PUU-XIII/20I 5 (delivered on 5 April 20I7) [City/ County Perda Review case]; and Constitutional Court of Indonesia, Decision No 56/PUU-XIV/20I6 (delivered on I4 June 2017) [Provincial Perda Review case].

6. Simon Butt and Tim Lindsey, Indonesian Law (OUP 2018). 
inherently effective mechanism for review of the many thousands of laws subnational governments have produced, at least compared with executive review.

Finally, the Court's decisions appear to be incomplete, which means, ironically, that its decisions might not ultimately have the effect the majority desired, for reasons I cover in Part VI. In particular, the majority left in force various provisions of the 2014 Regional Government Law that allow the national government to impose national standards and policies on subnational governments. These provisions allow the central government to invalidate non-compliant subnational laws, and they could form the basis for national executive review resembling the system the Constitutional Court had invalidated.

Before turning to these criticisms, I briefly introduce Indonesia's Constitutional Court and the system of regional autonomy that was affected by the Perda Review cases.

\section{REGIONAL AUTONOMY}

Decentralization, or 'regional autonomy' (otonomi daerah) as Indonesians usually call it, was an early priority for reformists in the post-Soeharto Reformasi period. ${ }^{7}$ Encouraged by donors, they expected autonomy not only to improve governance standards by 'bringing government closer to the people', ${ }^{8}$ but also to help assuage increasing resentment towards the repressive and strongly centralized state over which Soeharto had presided. This resentment had manifested in violent protest across many parts of Indonesia, which reformists feared would threaten Indonesia's national integrity. ${ }^{9}$

The basic features of Indonesia's decentralized system appear in Article I 8 of the I945 Constitution of Indonesia (Constitution). Indonesia is divided into provinces (propinsi); and provinces are divided into counties (kabupaten or 'regencies') and cities (kota), which are the same tier of government. Each province, county, and city has its own regional government (Article I 8(I)), comprising a regional people's representative council (Dewan Perwakilan Rakyat Daerah, DPRD) whose members are voted in by general election (Article I 8(3)), and a democratically elected regional head and deputy. These are governors (gubernur), regents (bupati), and mayors (walikota) in provinces, counties, and cities, respectively (Article I $8(4)$ ). Regional governments have wideranging autonomy, including the power to enact regional regulations (Perda) and other regulations (Article $\mathrm{I} 8(6)$ ), except in matters that national legislation reserves for the central government (Article I 8(5)). ${ }^{\text {IO }}$ In 2018 , Indonesia had thirty-four provinces and

7. For an excellent account of the reform process, and the reforms achieved, see Nadirsyah Hosen, Human Rights, Politics and Corruption in Indonesia: A Critical Reflection on the Post Soeharto Era (Republic of Letters 2010).

8. Vito Tanzi, Fiscal Federalism and Decentralization: A Review of Some Efficiency and Macroeconomic Aspects (World Bank I995) 295.

9. Donald L Horowitz, Constitutional Change and Democracy in Indonesia (CUP 2OI3).

Io. In this article, I use the word 'Perda' to refer to both a specific regional regulation, and regional regulations in general; and in both the singular and plural senses. 
over 500 cities and counties. ${ }^{\mathrm{II}}$ The total number of subnational administration has nearly doubled since Soeharto's rule ended, as provinces, counties, and cities have split to create new governments. ${ }^{\mathrm{I}}$

Like its predecessors of I999 and 2004, the 2014 Regional Government Law adds key details to this constitutional framework. For example, this law clarifies that governors, regents, and mayors can issue Perkada (peraturan kepala daerah, regional head regulations) to implement Perda or if required by law (Article 246(I)). It also establishes the relative jurisdictions of the various tiers of government and specifies matters falling within the exclusive jurisdiction of the central government: foreign affairs, fiscal and monetary policy, judicial matters, defence and security, and religion. ${ }^{\mathrm{I}}$

The 2014 Regional Government Law also sets out the process for the 'executive' or 'bureaucratic' review of Perda, which the Constitutional Court removed in the Perda Review cases. The Law required provincial Perda to be sent to the Ministry of Home Affairs, and city and county Perda to the governor of the province in which the city or county is located, within seven days of enactment, for review (Articles 249(I) and (3)). If the Perda conflicted with a higher law, the public interest, or morality, the Minister or governor could invalidate it. ${ }^{\mathrm{I}}$

These criteria were unclear and thus were undoubtedly difficult to apply. 'Morality' was defined as 'norms related to civilisation and politeness, good behaviour and excellent manners' (Elucidation to Article 250(I)). Of course, assessing legality on these 'morality' bases seems impossible, given that they appear to relate to human behaviour, rather than the characteristics of a law. 'Public order' was defined broadly to include disturbing inter-communal harmony, access to public services, public peace and order, or economic activity that increases the people's prosperity; and discriminating against an ethnic group, religion, belief, race, group, or gender (Article 250(2)).

The 'higher-level' laws ground mentioned in Article 25O(I) is a reference to Article 7 (I) of Law No I2 of 20 I I on Lawmaking (20I I Lawmaking Law), which sets out the types of legal instruments commonly used in Indonesia. The Constitution sits at the apex, followed by decrees of the People's Consultative Assembly, statutes, and interim emergency laws; government regulations; presidential regulations; provincial regulations; and county/city regulations. Provincial regulations sit 'above' county and city regulations, and must, therefore, prevail in the event of any consistency. All regional regulations sit below national statutes, government regulations, and presidential regulations, and are thus trumped by them.

\footnotetext{
I I. Anwar Nasution, 'Government Decentralization Program in Indonesia' (2015) Asian Development Bank Institute Working Paper Series No 60I, 4<www.adb.org/sites/default/files/publication/20 I I 6/adbiwp601.pdf $>$ accessed I 2 July 2018.

I 2. Anne Booth, 'Splitting, Splitting and Splitting Again: A Brief History of the Development of Regional Government in Indonesia Since Independence' (20II) I67(I) Bijdragen tot de Taal-, Land- en Volkenkunde 3 I.

I3. 2014 Regional Government Law, art Io (I).

I4. If the governor failed to invalidate a city or county Perda not meeting these criteria, the Minister could invalidate it.
} 
The hierarchy does not include many types of laws used in Indonesia today. The hierarchy itself acknowledges this and states that other instruments have legal force if the power to make them is delegated to an official or institution by a higher level law, or otherwise falls within the jurisdiction of that institution or official (Article 8). However, the precise legal authority of the types of laws covered by Article 8 - especially vis-à-vis laws that are listed on the hierarchy and vis-à-vis each other - is not explained and is hence unclear. This can be highly problematic where, for example, a minister issues a regulation that purports to invalidate a Perda or regulate central-local government relations. Whether a ministerial regulation has the authority to invalidate a Perda is highly contested, but unresolved.

A further issue of uncertainty is the relative authority of decisions (keputusan) vis-àvis regulatory instruments (peraturan). None of the instruments on the hierarchy are called 'decisions', but decisions are very commonly issued in Indonesia, particularly by the president, national government ministers, and heads of regional executive government. Formally, decisions are administrative determinations about an issue, such as the appointment and dismissal of a public officeholder, whereas regulations are typically broader in scope and contain rules that apply generally. However, lawmakers often use 'decisions' to perform regulatory functions. ${ }^{{ }^{5} 5}$ While some of these types of instruments should be deemed to be 'regulations', despite being called 'decisions' ${ }^{16}$ this is done inconsistently in practice, particularly by the courts. As discussed below, the relative status of decisions and regulations is critical to the operation of regional autonomy, particularly because the 20I4 Regional Government Law purports to authorize governors to issue 'decisions' to invalidate regional 'regulations'.

\section{THE CONSTITUTIONAL COURT}

The Constitutional Court was established in 2003 . It has various functions, including performing constitutional review, where it ensures that legislation complies with the Constitution, including the human rights provisions incorporated in 2000 , and can invalidate legislative provisions that it finds to be unconstitutional. It is the first Indonesian judicial institution with the power to perform constitutional review. The Court can also resolve disputes about the relative jurisdiction of state institutions, the dissolution of political parties, and general election results. It must also 'provide a decision' if the national parliament suspects that the president or vice president has committed treason or corruption, another serious crime or form of misconduct, or otherwise no longer fulfils the constitutional requirements to hold office. ${ }^{17}$

The Court attracted mostly positive assessments for its performance during its first decade or so, having invalidated many statutory provisions, and even entire statutes,

I 5. Jimly Asshiddiqie, Perihal Undang-Undang [About the Law] (Rajawali Pers 20I0) 9-I I.

I6. See art Ioo of the 20I I Lawmaking Law, which states that various types of decisions that have the character of a regulation must be treated as a regulation, if issued before the enactment of the 20 I I Lawmaking Law itself.

I7. Arts $24 \mathrm{C}(\mathrm{I})$ and $24 \mathrm{C}(2)$ of the Constitution, and art ro of Law $\mathrm{No} 24$ of 2003 on the Constitutional Court (2003) Constitutional Court Law). 
for violating constitutional principles. That it would perform the constitutional review function professionally was by no means certain given Indonesia's long history of judicial dependence on government, corruption, and decrepitude. ${ }^{18}$ Under the leadership of its founding chief justice, Professor Jimly Asshiddiqie (2003-2008), the Court built a reputation for issuing relatively well-reasoned decisions and for high levels of independence - as between the presiding judges, as evidenced by the relatively high rates of dissenting judgments, and from 'outside' political interests and the lure of corruption. The second chief justice, Professor Mahfud MD (2008-20I3), largely maintained the Court's integrity, while increasing its 'activism'. ${ }^{\text {'9 }}$

However, this professionalism was not maintained under the leadership of the Court's third chief justice, Akil Mochtar (April - October 2013). Mochtar himself was caught red-handed taking a bribe to fix electoral disputes, for which he was convicted and imprisoned for life in 20I $4 .{ }^{20}$ Even though the Court appeared to move towards restoring its reputation under his replacement, Hamdan Zoelva (October 20I3-20I 5), corruption scandals emerged again under the leadership of Arief Hidayat (2015 present). In 20I7, another Constitutional Court judge, Patrialis Akbar, was convicted and sentenced to eight years' imprisonment for receiving money to influence a constitutional review case. ${ }^{2 \mathrm{I}}$ As we shall see, his subsequent removal from the bench contributed to the Court's questionable decision-making processes in the Perda Review cases. One also gets the impression that the reasoning of the Court has, in some cases at least, become less convincing since the Mahfud era. The Perda Review cases are clear examples of this, as demonstrated in Part III below. Nevertheless, these problems have not discouraged litigants, who are bringing cases to the Court with increasing frequency. ${ }^{22}$

\section{THE PERDA REVIEW CASES}

The first of the Perda Review cases - City/County Perda Review case $e^{23}$ - was brought by over forty county governments and the Indonesian Association of County

I8. Simon Butt and Tim Lindsey, 'Judicial Mafia: The Courts and State Illegality in Indonesia' in Edward Aspinall and Gerry van Klinken (eds), The State and Illegality in Indonesia (KITLV Press 2010) I 89; Sebastiaan Pompe, The Indonesian Supreme Court: A Study of Institutional Collapse (Cornell Southeast Asia Program 2005); John Pemberton, 'Open Secrets: Excerpts from Conversations with a Javanese Lawyer, and a Comment' in Vicente L Rafael (ed), Figures of Criminality in Indonesia, the Philippines, and Colonial Vietnam (Cornell Southeast Asia Program r999) I93; Daniel S Lev, 'Judicial Institutions and Legal Culture in Indonesia' in Claire Holt (ed), Culture and Politics in Indonesia (Cornell University Press I972) 246.

I9. Simon Butt, 'Indonesia's Constitutional Court - Conservative Activist or Strategic Operator?' in Björn Dressel (ed), The Judicialization of Politics in Asia (Routledge 20I2) 98.

20. Haeril Halim, 'Historic sentence for Akil' The Jakarta Post (Jakarta, I July 20I4) < www.thejakartapost. $\mathrm{com} /$ news/20I4/07/OI/historic-sentence-akil.html > accessed 6 October 2018.

2I. Kharishar Kahfi, 'Former MK justice sentenced to 8 years in prison' The Jakarta Post (Jakarta, 4 September 20I7) <www.thejakartapost.com/news/20I7/09/04/corruption-court-to-issue-verdict-forformer-mk-justice.html $>$ accessed 6 October 2018 .

22. For statistics, see Constitutional Court of the Republic of Indonesia, 'Recapitulation of Cases' (Constitutional Court of the Republic of Indonesia) <www.mahkamahkonstitusi.go.id/index.php? page $=$ web.RekapPUU\# $>$ accessed I3 July 20 I 8.

23. (n 5). 
Governments. ${ }^{24}$ They challenged the constitutionality of various provisions of the 2OI 4 Regional Government Law, including those dealing with executive review. ${ }^{25}$ The applicants argued that these provisions were unconstitutional for two main reasons. The first was that they contravened Article I 8 of the Constitution, which does not limit the jurisdiction of subnational lawmakers by making their laws subject to central government review. ${ }^{26}$ The second was that executive review usurped the power of the Supreme Court to review subnational laws. ${ }^{27}$

\section{A. The Majority Decision}

The majority decision began by emphasizing that, while Indonesia's national motto is Bhinneka Tunggal Ika (commonly translated as 'Unity in Diversity'), the 'Unitary State of the Republic of Indonesia' (Negara Kesatuan Republik Indonesia) is a constitutional principle so important that Article $37(5)$ of the Constitution declares it to be unalterable. ${ }^{28}$ However, Indonesia's size and geographical spread make it impossible for a single national government to control the entire state; subnational governments are thus necessary. These subnational governments have enjoyed varying levels of authority during different periods of Indonesian history. For example, before Indonesia declared its independence in 1945, they exercised significant autonomy. But under the highly centralist New Order, their responsibilities were curtailed, making them unable to 'determine their own direction'. ${ }^{29}$ As the majority put it: '[e]verything depended on the attention and rewards of the central government'. ${ }^{\circ}$

The majority observed that reformists prioritized regional autonomy in the postSoeharto period, not only as a reaction against centralism, but also hoping for accelerated community prosperity through improved services and public participation in government. ${ }^{3 \mathrm{I}}$ Article $\mathrm{I} 8$ of the Constitution was thus amended to provide subnational governments with autonomy that was 'as broad as possible'. As part of this autonomy, the central government also granted limited powers to regional governments to issue Perda. ${ }^{32}$ According to the majority, 'Perda can regulate all matters of government and community interest not regulated by the centre', 33 but

24. Asosiasi Pemerintah Kabupaten Seluruh Indonesia (APKASI).

25. Some of the applicants' arguments fall beyond the scope of this article because they did not relate to city and county regulation invalidations, focusing instead on the county and city governments' lack of exclusive responsibilities or jurisdiction. In any event, the Court did not consider the merits of these jurisdictional arguments because the constitutionality of the $20{ }_{4} 4$ Regional Government Law's division of jurisdiction had already been decided in a previous case: Constitutional Court of Indonesia, Decision No $87 /$ PUU-XIII/20I 5 (delivered on I3 October 20I6). The Court said that the reasoning there could be applied to this case.

26. City/County Perda Review case (n 5 ) I 87.

27. ibid.

28. Of course, the claim that art $37(5)$ is unalterable cannot be maintained, given that its claim to unalterability can be removed by the same amendment procedures, also contained in art 37 , that apply to any other constitutional provision.

29. City/County Perda Review case (n 5) I97.

30. ibid.

3I. ibid I98.

32. ibid I99.

33. ibid 200. 
cannot operate beyond the physical jurisdiction of the local government, whereas legislation issued by the central government operates nationally. ${ }^{34}$ The majority also emphasized that local governments and the central government needed to 'work together to solve problems and govern the country', but that some matters were reserved exclusively for national government control. ${ }^{35}$

The majority acknowledged that, in a unitary state, the higher level of government should logically have power to control lower government units - that is, the central government should control provincial, city, and county governments; and provincial governments should control city and county governments. One way to achieve this control is through what the majority called 'executive abstract preview'. This involves the higher government reviewing lower government laws while still in draft form. However, once the Perda is enacted and becomes binding, the national government should lose these review powers. For the majority:

it is best that a judicial institution reviews it, as a third party which is not involved in the process of creating the Perda in question, in accordance with the system adhered to and developed through the 1945 Constitution - that is, the centralised model of judicial review, not the decentralised model. ${ }^{36}$

Without much explanation, the majority then noted that judicial review is a prerequisite to the rule of law (negara hukum) and that it is 'only properly conducted by a judicial institution'. ${ }^{37}$ The majority seemed to justify this on democratic grounds, stating:

Perda are created by regional heads and parliaments, both of which are elected democratically. Perda are created based on the principle of the people's sovereignty, because they are created by executive and legislative bodies. Formally, the creation of a Perda is the result of the sovereignty of the people exercised through the local regional head and parliament. The people's sovereignty is mandated by Article I(2) of the Constitution..$^{38}$

The majority then affirmed that the Supreme Court could, in fact, judicially review Perda, citing various iterations of Law No 48 of 2009 on Judicial Power (2009 Judicial Power Law), which provide that the Supreme Court can review laws below statutes to ensure their compliance with statutes. ${ }^{39}$ The majority concluded, then, that reviewing Perda on grounds of breach of a higher law was one of the Supreme Court's functions. So, too, was reviewing Perda on grounds of morality or public interest, because both morality and public interest were defined by the 2014 Regional Government Law. ${ }^{\circ}$ The argument here appears to be that, because the public interest and morality are defined by statute, reviewing Perda by reference to them would, in essence, be

\footnotetext{
34. ibid 20I.

35. ibid 198 .

36. ibid 204 .

37. ibid 203.

38. ibid.

39. ibid 202-203.

40. ibid 205 .
} 
reviewing Perda against statutes, or at least statutory norms, and thus fell within the Supreme Court's judicial review powers.

Having established that the Supreme Court, not the central government, could and should review Perda, the Court considered another issue: whether a city or county Perda could, in any event, legally be invalidated by gubernatorial decision, as Articles $25 \mathrm{I}(2)$ and (3) of the 20I4 Regional Government Law had specified. The majority decided that it could not, for two reasons.

First, the Court found that Articles 25 I(2) and (3) did not 'accord with the regime of laws adhered to in Indonesia', because the 'hierarchy of laws' does not mention gubernatorial decisions. ${ }^{4 \mathrm{I}}$ The Court continued: 'In other words, according to the Court, a mistake has occurred, whereby County/City Perda - legal instruments that regulate - can be invalidated by a gubernatorial decision, a legal instrument that takes the form of a decision'. ${ }^{2}$

Second, the Court found that using a gubernatorial decision as the legal instrument to invalidate Perda could 'cause dualism in judicial decisions' ${ }^{43}$ This was because a gubernatorial decision was an administrative decision that could be challenged in Indonesia's administrative courts. If a gubernatorial decision to invalidate a Perda was successfully challenged there, then the Perda would come back into force. Yet, on the other hand, the Perda could also be reviewed by the Supreme Court under its general judicial review jurisdiction. This could lead to the invalidation of the Perda. The Court said:

[If this happens], then dualism has occurred on the same issue. The potential for dualism between administrative court decisions and review decisions by the Supreme Court in respect of a case with the same substance, but only with a different legal problem, will cause legal uncertainty... ${ }^{44}$

The majority concluded that this dualism violated Article $28 \mathrm{D}(\mathrm{I})$ of the Constitution, which provides the right to legal certainty. For these reasons, the majority invalidated the governor's power to revoke city and county Perda under Articles $25 \mathrm{I}(\mathrm{I})-(4)$ of the 2014 Regional Government Law. ${ }^{45}$ The majority decision has little to commend it, for three broad reasons which I now discuss.

\section{Supreme Court's judicial review power}

The majority concluded that the Supreme Court can review Perda. While the Supreme Court clearly has the power to test the legality of Perda, the particular instruments against which it can test them is not clear and has been a much vexed legal issue in Indonesia for decades. The unresolved question is whether the Supreme Court can

\footnotetext{
4I. ibid 205-206.

42. ibid 206.

43. ibid.

44. ibid.

45. Art $25 \mathrm{I}(8)$ of the $20 \mathrm{I}_{4}$ Regional Government Law, which covered objections to invalidation of Perda before the Supreme Court, thereby lost its relevance, and was also invalidated: City/County Perda Review case (n 5) 206-207.
} 
review Perda as against any higher-level laws, or only as against statutes. The Constitutional Court entirely ignored this question. As discussed in Part I, no such uncertainty existed about executive review: the Ministry of Home Affairs and governors had been able to review Perda for compliance with any higher-level law, statute or not.

The source of the uncertainty about the Supreme Court's judicial review power is the different expression of that power in different legal instruments. On the one hand, the Constitution, the Supreme Court Law, and the 2009 Judicial Power Law appear to limit the Supreme Court to reviewing regulatory instruments 'below a statute against statutes' ${ }^{46}$ This must be considered the dominant position, given that it is established by the Constitution itself. However, the Supreme Court Law and the 2009 Judicial Power Law imply, in other provisions, that the Supreme Court can review any law below a statute against any law higher than it on the hierarchy - and not necessarily a statute. ${ }^{47}$ Importantly, Supreme Court Regulation No I of 20 I I specifies that judicial review is the 'right of the Supreme Court to evaluate the substance of a law below a statute against a higher-level law' (Article I(I)). While this Regulation has legal force by virtue of Article 8 of the 20I I Lawmaking Law, it is really just an internal set of guidelines for judges when deciding cases, and legally is clearly inferior to statutes, much less the Constitution. Nevertheless, many Supreme Court judges defer to the Regulation when deciding review cases. The result has been inconsistent Supreme Court decisions: in some cases, the Court has held that its jurisdiction is confined to reviewing lower-level laws against statutes; in others, the Court has taken a broader view, for example hearing Perda reviews against presidential decisions. ${ }^{48}$

\section{Democracy justification}

The majority reasoned that, because local legislatures and executives are democratically elected, the laws they produce should not be easily thwarted by a higher level of government. ${ }^{49}$ If permitted, this would violate the sovereignty of the people who elected the local government. Instead, subnational laws should be reviewed by a judicial institution, which is a 'third party'.

This democratic argument is weak for two main reasons. First, the higher-level laws against which Perda might be reviewed will often have their own democratic legitimacy. National statutes are, of course, enacted by the national legislature, which is democratically elected. The head of the national executive, the president, is also directly elected in Indonesia. This arguably lends democratic legitimacy to the regulations that require his or her signature, such as government and presidential

46. Art $24 \mathrm{~A}(\mathrm{I})$ of the Constitution; art 20 (2) of Law No 48 of 2009 on Judicial Power (2009 Judicial Power Law); art $3 \mathrm{I}(\mathrm{I})$ of Law No 5 of 2004 (amending Law No I4 of I985) on the Supreme Court (Supreme Court Law).

47. Art 3 I (2) of the Supreme Court Law, for example, states that the 'Supreme Court is to declare a law below a statute invalid if it conflicts with a higher-level law.' Similarly, the Elucidation to art 20(2) of the 2009 Judicial Power Law refers to 'the Supreme Court's judicial power to review legal instruments lower than a statute'.

48. Simon Butt and Nicholas Parsons, 'Judicial Review and the Supreme Court in Indonesia: A New Space for Law?' (2014) 97 Indonesia 55.

49. City/County Perda Review case (n 5$) 204$. 
regulations. It might also be argued that presidential legitimacy extends to officials who hold their offices at the pleasure of the president (such as ministers) and the laws they produce (such as ministerial regulations). It is also worth noting that governors, who could previously review county and city Perda, are directly elected by citizens in their provinces, including citizens who live in the county or city where the Perda was enacted. To emphasize the democratic legitimacy of the Perda-maker over all others, therefore, seems simplistic.

The second reason is that the Supreme Court is, itself, not democratically elected. If democratic legitimacy is the yardstick, then this becomes problematic. To be sure, the government and national legislature are involved in the appointment of judges, but judges cannot be as easily removed as, for example, a minister or other official who can be removed by the president. This is because, in Indonesia, as elsewhere, judges are now formally independent of government. ${ }^{50}$ Of course, unelected judges invalidating laws enacted by democratically elected lawmakers has long posed questions for political scientists and constitutional law scholars the world over. ${ }^{5 \mathrm{I}}$ Nevertheless, the majority did not even mention this issue, despite its relevance to the arguments the majority made about democracy and judicial review.

\section{Gubernatorial decision as an invalidation instrument}

As mentioned, the majority found that a gubernatorial decision (which is not on the hierarchy of laws) cannot invalidate a Perda (which is on the hierarchy of laws). This bold finding obscures significant controversy and complexity. On the one hand, this seems to sit comfortably alongside a cursory reading of the 20 I I Lawmaking Law. As mentioned, even laws not expressly mentioned in the hierarchy can have legal force, provided that the lawmaker has authority to issue them or a higher-level law authorizes them (Article 8(2)). Article 8(I), which establishes the institutions and individuals with the power to issue these laws not mentioned in the hierarchy, mentions 'governors'. However, Article 8(I) refers only to the 'peraturan' (regulations) that these institutions or individuals make, not the 'keputusan' (decisions). On this reading, any 'decision', whether made by a local government leader, a minister, or even the president, does not have any formal binding force, even if authority to issue the decision was delegated by higher-level law, including a statute.

But there is some doubt about this interpretation. On another reading, a gubernatorial decision, if made by delegation of authority from a national statute, should have the status of that statute. Applied to this case, any gubernatorial decision issued pursuant to the 20I4 Regional Government Law could be considered as an

50. 'Kekuasaan Kehakiman Satu Atap, Anggaran MA Membengkak [Judicial Authority under One Roof, MA Budget Swells]' (Hukumonline, 4 September 2004) <www.hukumonline.com/berita/baca/ holı I087/kekuasaan-kehakiman-satu-atap-anggaran-ma-membengkak $>$ accessed 2 July 2018.

5I. Mark A Graber, 'Foreword: From the Countermajoritarian Difficulty to Juristocracy and the Political Construction of Judicial Power' (2006) 65 (I) Maryland Law Review I. Of course, the Kelsenian view is that judicial review is legitimate because it is permitted by the Constitution - the 'highest law' or the ultimate source of legal legitimacy, which is assumed to express the will of the people. In this sense, 'the erosion of legislative sovereignty [is simply] necessary to guarantee the normative superiority of the constitution through constitutional review': Alec Stone Sweet, Governing with Judges: Constitutional Politics in Europe (OUP 2000) I $34-\mathrm{I} 35$. 
extension of the authority of the national legislature, and hence would prevail over a Perda. Because any such gubernatorial decision was authorized by statutory regulation, it might also be argued that the gubernatorial decision should be given the authority of a regulatory instrument rather than a mere decision. The weakness in this interpretation is that local governments also derive authority to issue Perda from the very same statute, and even the Constitution itself, in Article I8. Following this logic, a Perda should prevail over gubernatorial decisions, because local governments have constitutional authority to issue Perda, whereas governors have only statutory authority to issue decisions.

There is yet another interpretation. The $20{ }_{4} 4$ Regional Government Law provisions empowering governors to issue decisions to invalidate Perda were enacted after the 20I I Lawmaking Law came into force. Even though the 20I I Lawmaking Law is central to the operation of the legal system, it has no special legal status. It is arguable that, even if the Constitutional Court's application of the hierarchy rules was correct (which, as I have argued, is doubtful), the more recent and specific 20I4 Regional Government Law (which grants express power to governors to invalidate Perda) should prevail over the 20I I Lawmaking Law, whatever its operation. This conclusion comes from relatively straightforward applications of the lex posteriori derogat lex priori (a more recently enacted law prevails over an earlier law if they conflict) and lex specialis derogat lex generalis (a specific law prevails over a law of a general nature if they conflict) maxims, which prevail in Indonesia.

It bears noting that the precise status of gubernatorial decisions has been contentious in the Supreme Court, particularly in cases where applicants have sought their review against a higher-level law. In some cases, the Supreme Court has refused to review gubernatorial decisions, ${ }^{52}$ holding that its judicial review jurisdiction does not extend to those instruments: as administrative decisions, they should instead be challenged in the administrative courts. These cases seem consistent with the majority's decisions in the Perda Review cases. Yet in other cases, the Supreme Court has decided to review gubernatorial decisions, either without further explanation, ${ }^{53}$ or holding that they are captured by Article 8(I) of the 20 I I Lawmaking Law. ${ }^{54}$ The Constitutional Court did not mention these inconsistent Supreme Court decisions.

The majority was concerned that using a gubernatorial decision to invalidate Perda resulted in dualism, because this could result in the production of two different judicial decisions relating to a single issue. On the one hand, a gubernatorial decision is an administrative decision and can, therefore, be challenged in Indonesia's administrative courts. According to the majority, the Perda would revive if the gubernatorial decision was invalidated. On the other hand, citizens can apply to the Supreme Court for review

52. Supreme Court of Indonesia, Decision No $5 \mathrm{I}$ P/HUM/20I2, reviewing Central Sulawesi Governor Decision No I7I/533/RO.ADM PUM-G-ST/20I 2, I October 20 I 2 (delivered on I I December 20I4).

53. Supreme Court of Indonesia, Decision No ог P/HUM/20I4, reviewing Riau Governor Decision No 984 of 20I3, 2I November 2013 (delivered on 7 January 20I 5 ).

54. Supreme Court of Indonesia, Decision No I4 P/HUM/20I7, reviewing Article 2 of Jakarta Governor Decision No 640 of 1992 and Jakarta Governor Decision No I934 of 2002 (delivered on I7 April 2017), I9; Supreme Court of Indonesia, Decision No 65 P/HUM/20 I4, reviewing Jakarta Governor Decision No 23 of 2003 (delivered on 7 January 2015). 
of the Perda to which a gubernatorial decision related. This might result in the Perda being invalidated.

Unfortunately, the majority's reasoning here was, again, not convincing. The majority only complained about the general undesirability of having decisions from different courts about the 'same issue'; it did not identify the problem this caused with any specificity. Nevertheless, it is difficult to see how having two available legal avenues - an administrative law challenge and a judicial review application - will lead to uncertainty, or at least to a level of uncertainty that required Constitutional Court intervention. This is because one of the Supreme Court's functions is resolving jurisdictional disputes between courts. ${ }^{55}$ The Supreme Court could, therefore, stay proceedings in an administrative court until a related judicial review application had been resolved, and vice versa.

Also problematic was the Court's assertion that a Perda would spring back to life if the gubernatorial decision invalidating it was itself struck down by an administrative court. This is by no means certain. Whether a revoked law will automatically revive if the instrument that revoked it is itself invalidated has long been debated by Indonesian legal scholars. The Court's treatment of the issue did not discuss this debate, let alone settle it.

This issue came to the fore in 2014, when then-President Susilo Bambang Yudhoyono issued an emergency law to invalidate a statute that had been enacted by parliament in the previous week. ${ }^{56}$ Amongst other things, the statute had removed the requirement that governors, regents, and mayors be directly elected, and it had reestablished the practice under which they were elected by their respective subnational parliaments. ${ }^{57}$ This change was condemned as anti-democratic and was deeply unpopular, prompting Yudhoyono to issue the emergency law to reinstate direct elections.

The Constitution grants power to the president to issue interim emergency laws in pressing circumstances. ${ }^{58}$ When issued, emergency laws have the legal force of statutes, but they must be endorsed by the national parliament at its next sitting to remain in force. ${ }^{59}$ One question arising from this scenario was whether the statute the emergency law sought to replace would revive if the emergency law was not endorsed by parliament at its next sitting or was invalidated by the Constitutional Court. Some legal scholars claimed that it would revive. Others disagreed, arguing that the emergency law would have done its 'job' - to remove the statute - once the president issued it, even if parliament or the Court ultimately rejected it. ${ }^{60}$ Following this thinking, the result

\footnotetext{
55. See Law No I 4 of 1985 on the Supreme Court, arts 56-65.

56. Interim Emergency Law No I of 20I4, which invalidated Law No 22 of 2014 on Election of Governors, Regents and Mayors. See also Interim Emergency Law No 2 of 2014 and the amended provisions in the 2014 Regional Government Law that provided for direct regional head elections.

57. Law No 22 of 2014 on Election of Governors, Regents and Mayors, art 3.

58. See Constitution, art 22.

59. ibid art 22(2).

6o. 'Ini Bahayanya Jika Perpu Pilkada Langsung Ditolak DPR [This is the Danger if Direct Elections are Rejected by the DPR]' (Detik News, 4 December 20I4)< https://news.detik.com/berita/2767498/inibahayanya-jika-perpu-pilkada-langsung-ditolak-dpr $>$ accessed 2 October 20I8. The Indonesian Constitutional Court has long held the view that its decisions operate only prospectively. That is, a
} 
would be a legal vacuum that would require parliamentary action. This action could be either a new statute or the express re-enactment of the statute invalidated by the emergency law.

\section{B. Dissenting Opinion}

Chief Justice Arief Hidayat and Justices I Dewa Gede Palguna, Maria Farida Indrati, and Manahan MP Sitompul issued a joint dissent. Like the majority, the minority emphasized that Indonesia is a unitary state, meaning that there is only one legal system in which both the central and regional governments operate. Unlike in federal systems, the minority observed, the jurisdictions of the central and subnational governments are not clearly demarcated in Indonesia. The minority continued:

In a unitary state, no matter how broad the autonomy given to the regions ... and no matter how particular or special [the autonomy] given to a region, the extent and variety of special autonomy given to regions cannot be understood as a basis to ignore the principle of a single legal system so that it becomes thought that there are two legal systems applicable in the Unitary Republic of Indonesia. ${ }^{61}$

For the minority, this 'single legal system' was for the central government to maintain and control. To support this stance, the minority pointed to the General Elucidation to the 20I4 Regional Government Law, which states that:

Provision of broadest autonomy to regions is based on the principle of the unitary state. In the unitary state, sovereignty is only in the state or national government, and there is no sovereignty for the regions. Therefore, however broad the autonomy given to the regions, the ultimate responsibility for the running of local government remains in the hands of the central government. For this, the regional government in a unitary state is at one with the national government... The regions... have autonomy to regulate and administer their regions in accordance with the aspirations and interests of their communities provided that they do not violate the national legal order and public interest. ${ }^{62}$

Having established the superiority of the central government within the unitary state structure, the minority made several observations about the power to invalidate decisions under Indonesian administrative law. As the minority described it, invalidation aims to protect parties and the community from a government decision with a formal or substantive defect, and to negate the legal effects arising from that decision. The official who made the decision, his or her superior, or an administrative court can perform the invalidation. Here, however, the Court was not dealing with the invalidation of a 'decision': a Perda is, as mentioned, a regulation of general application. The minority acknowledged this, but found that, in this case, Perda could

statute that is declared to be invalid is only invalid at the time the Court invalidates it. Any action taken under that law will itself be legal, at least until that law is invalidated: Simon Butt, 'Judicial Review in Indonesia: Between Civil Law and Accountability? A Study of Constitutional Court Decisions 2003 2005' (PhD Dissertation, Law Faculty, Melbourne University 2007).

6I. City/County Perda Review case (n 5 ) $2 \mathrm{I}_{3}$.

62. ibid. 
be treated as if they were decisions for the purposes of invalidation. ${ }^{63}$ This was because, according to Article 4 of the Constitution, the President holds government authority (memegang kekuasaan pemerintahan) and is therefore responsible for the implementation of regional autonomy.

Therefore, the president has an interest and legal basis to ensure that a government unit falling under his or her responsibility - in this case, regional government - does not breach higher level laws, public order, and/or morality. ${ }^{64}$ In other words, the president could legitimately invalidate a subnational law, whether decision or regulation, because, as head of government, the president was the 'superior' of subnational governments.

The minority also noted that Article I(2) of the 20 I $_{4}$ Regional Government Law stipulates that regional governments are implementers of central government functions'. Both subnational legislatures and regional heads perform these functions. In this context, the minority thought that the national government must be able to exercise control over the content of subnational laws, particularly if they violated nationally stipulated guidelines. The minority said:

Therefore, arguing that the norm giving authority to the President... to invalidate Perda and regional head regulations is unconstitutional is the same as saying that regional government is not part of the government authority for which the president is ultimately responsible. The same goes for the argument that the norm giving authority to the President... to invalidate Perda is unconstitutional... [This] is the same as saying that the regional parliament is not part of the local government administration. ${ }^{65}$

The minority also urged that the constitutionality of executive review be considered in light of the fact that regional governments had only ever been granted 'attributive authority' (atribusi kewenangan) under Article I 8(6) of the Constitution and Article 236 of the 2014 Regional Government Law, rather than a fuller 'delegated authority' (delegasi kewenangan). ${ }^{66}$ Both derive their authority from a statute or a higher-level law, but the former has the legal status of the delegate, while the latter has the legal status of the authorizing instrument. ${ }^{67}$

For the minority, this was an important distinction. If local governments made Perda under 'delegated authority', then Perda would, in effect, have the legal status of a statute, because it derived its authority from a grant of power under the 2014 Regional Autonomy Law. By contrast, if they made Perda under 'attributive authority', then the status of the Perda would follow the hierarchy, sitting below national regulations. The minority concluded that local governments had only ever been granted attributive authority, because otherwise Perda would have the same authority as national statutes and would, therefore, trump national regulations

\footnotetext{
63. ibid 2 I 5 .

64. ibid 216.

65. ibid 217 .

66. ibid 2I4-2I5.

67. Maria Farida Indrati S, Ilmu Perundang-undangan: Jenis, Fungsi, dan Materi Muatan [The Study of Laws: Types, Function, and Content] (Kanisius 2007) 54-56.
} 
sitting below statutes on the hierarchy. ${ }^{68}$ Although the minority did not articulate its argument here clearly, the thrust appears to be that granting this level of power to subnational governments could not have been the intention of the architects of regional autonomy.

Like the majority, the minority mentioned the Supreme Court's judicial review power, but dedicated very little space to it. Unlike the majority, however, the minority held that executive review did not interfere with or usurp it. ${ }^{69}$

\section{Analysis of the dissent}

While Constitutional Court judges have always been able to issue dissenting opinions, majority and dissenting opinions rarely refer to each other, let alone attempt to counter competing arguments. ${ }^{70}$ This decision followed this trend, so, for example, the minority did not mention central arguments put by the majority, such as those based on democracy, let alone attempt to explain why it refused to follow those arguments.

The minority decision contained only one constitutional argument, based on Article 4 of the Constitution, which states that the president is the head of government. The minority found that this included local governments, both legislative and executive. Problematically, however, the minority reached this conclusion by reference to the General Elucidation to the 20I4 Regional Government Law. Whether a statutory provision can legitimately be used as an aid to constitutional interpretation is highly doubtful, given that the reference point for constitutional review is necessarily the Constitution. Even more questionable is using an elucidation of a statutory provision for this purpose. Elucidations provide authoritative interpretations of the provisions they purport to elucidate, but they are not formally binding and do not even constitute part of the statute containing those provisions. ${ }^{7 \mathrm{I}}$

The minority also appeared to obscure an important point about the separation of powers - here, the separation of legislative and executive power. Having the president exercise control over subnational executive governments seems consistent with the president being the head of the national executive in a 'unitary state'. After all, regional heads, particularly governors, are said to be the 'representatives of the national government' (Article 9I). However, it is by no means clear why the president's control should extend to a subnational legislature. If legislative and executive authority is to be kept separate, then should this function be left to the national legislature?

The minority's classification of local government authority to issue Perda as 'attributive' seemed sound, but associated arguments appeared to be incomplete. Its finding that subnational governments had received 'attributive authority' supports the conclusion that the 2014 Regional Government Law, which granted local governments

\footnotetext{
68. City/County Perda Review case (n 5) 2 I 5.

69. ibid 217.

70. Butt, 'Judicial Review in Indonesia: Between Civil Law and Accountability?' (n 60) 200.

7I. While statutes are formally printed in the State Gazette (Berita Negara), elucidations appear in a separate publication - the Appendix to the State Gazette (Tambahan Berita Negara).
} 
power to issue Perda, could also subject this power to executive review, though the minority did not expressly make this point. If this was the minority's intention, then the minority failed to consider that the Constitution itself - which clearly sits above the 2014 Regional Government Law - grants power to subnational governments to issue Perda, but does not expressly confine it.

\section{Provincial Perda Case}

A few months later, on I4 June 20I7, the Court handed down a decision of similar effect - but this time concerning provincial Perda. ${ }^{72}$ The Court referred to the majority reasoning in the City/County Perda Review case ${ }^{73}$ to invalidate Articles $25 \mathrm{I}(\mathrm{I}),(2)$, (7), and (8) of the 20I4 Regional Government Law. These provisions had allowed the Minister of Home Affairs to review and invalidate provincial-level Perda. Also included in the judgement is a statement indicating that the judges who dissented in the City/County Perda Review case maintained their dissent in this case. ${ }^{74}$ The Court did not identify any legal or constitutional difference between invalidation by gubernatorial decision and invalidation by ministerial decision. For the majority, neither could usurp the function of judicial review.

\section{DECISION-MAKING PROCESS: NO CLEAR MAJORITY}

The decision-making process in both the City/County Perda Review and the Provincial Perda Review cases was suspect, although this went largely unnoticed in Indonesia's legal community. ${ }^{75}$ Included on the nine-judge panel hearing the City/County Perda Review case was Patrialis Akbar, who had served as Minister of Justice before taking up a position on the bench. Akbar also participated in a judge's meeting about the case on 20 August 2016. However, by the time the Court met on 2 February 2017 and 30 March 2017 to discuss the case again, and when the decision was read out in open court, he had been suspended from office and was being prosecuted for taking a bribe to fix the outcome of another Constitutional Court case ${ }^{76}$ (as mentioned, later in 20I7, he was convicted and sentenced to eight years' imprisonment.) Yet without him and his vote, the Court was evenly split - four judges to four. The Court did not acknowledge this, with the judgment simply presenting the majority decision as the decision of the Court, before naming four judges who had issued a dissenting opinion and setting out that dissent.

72. Provincial Perda Review case (n 5 ).

73. See City/County Perda Review case (n 5) [3.I 2.4].

74. ibid ıоo.

75. This section draws on Simon Butt, 'Constitutional Court Lets Local Governments Off the Leash' (Indonesia at Melbourne, 4 July 2017) < http://indonesiaatmelbourne.unimelb.edu.au/constitutionalcourt-lets-local-governments-off-the-leash/> accessed I 2 July 20 I 8.

76. Patrialis Akbar was removed on 27 January 2017: Yustinus Paat and Eko Prasetyo, 'Patrialis Akbar Dismissed from Constitutional Court' (Jakarta Globe, 28 January 20I7) < http://jakartaglobe.id/news/ patrialis-akbar-dismissed-constitutional-court $>$ accessed I 2 July 2018. 
Whether a judge needs to be present during hearings, and during all deliberation meetings, to have his or her 'vote' count is not regulated under Indonesian law. But if this case is anything to go by, it appears that a judge need not be present at all important events related to proceedings. Unfortunately, this weakens the authority of a court's decisions, leaving it open to allegations that decisions do not properly represent the opinions of all the judges, or even that decisions may have been manipulated. In my view, the Constitutional Court should have considered itself to be 'split', which by law would have left the chief justice with the casting vote. ${ }^{77}$ This did not happen in the case because Chief Justice Arief Hidayat was in the minority.

Similar issues arose in the Provincial Perda case. This time, Akbar's replacement, Professor Saldi Isra, was not appointed until after the Court had finished hearing the case, but the decision states that he participated in the sole judges' deliberation meeting. ${ }^{78}$ Again, this raises questions about whether judges must participate in hearings and the judicial deliberations in which the decision is made if they are to have their vote count. Again, the case seems to indicate that judges do not need to be present at both. Yet, once again, if Isra's vote was excluded, the Court would have been split four judges to four.

\section{CONSEQUENCES}

If the Court's legal reasoning and decision-making processes were highly problematic, so too was its apparent failure to consider the consequences of its decisions in the Perda Review cases. I cover two particularly parlous consequences here. The first was removing executive or bureaucratic review. Though not without its own problems, many thousands of apparently egregious Perda had been invalidated using this mechanism before the Constitutional Court removed it. The second, related to the first, is giving exclusive authority to review Perda to the Supreme Court. The track record of the Supreme Court in judicial review cases is poor, and its powers are not inherently suited to the effective review of the many thousands of Perda currently in force, and the thousands of new Perda enacted each year.

\section{A. Removing Executive Review}

Although many subnational lawmakers are undoubtedly well-intentioned and professional, and have helped their communities in important areas such as health, education, and environmental standards, ${ }^{79}$ others are suspected of being incompetent and self-interested. Many appear to be corrupt: around 350 regional heads were

77. Art $45(8)$ of the 2003 Constitutional Court Law, as amended by Law No 8 of 20 I I.

78. Provincial Perda Review case (n 5 ) 102.

79. Blane D Lewis, 'Decentralised Government: Greater Demand Needed to Raise Service Quality in Indonesia' (East Asia Forum, 22 April 20I4)<www.eastasiaforum.org/20I4/o3/22/decentralisedgovernment-greater-demand-needed-to-raise-service-quality-in-indonesia/ > accessed I 2 July 20I7; Blane D Lewis and Daan Pattinasarany, 'Determining Citizen Satisfaction with Local Public Education in Indonesia: The Significance of Actual Service Quality and Governance Conditions' (2009) 4O(I) Growth and Change 85 . 
involved in corruption scandals, and almost 80 were caught 'red-handed' by the AntiCorruption Commission, between 2004 and 2016..$^{\circ 0}$ A primary concern, voiced by politicians and scholars alike, is that many subnational lawmakers have primarily used their lawmaking powers to raise revenue. Of course, governments need revenue to function, but many subnational governments in Indonesia have imposed user chargers for no identifiable government-provided services and taxes that duplicate those imposed by another tier of government. ${ }^{8 \mathrm{I}}$ These laws are said to damage the investment climate, particularly in regional areas, because they create a high cost economy'. ${ }^{82}$ Another concern is that some subnational laws have been oppressive or discriminatory, or adopt Islamic norms. ${ }^{83}$ For example, the National Women's Rights Commission (Komnas Perempuan) identified $42 \mathrm{I}$ by-laws that discriminated against women and minorities between 2009 and $2016 .{ }^{84} \mathrm{~A}$ more general criticism relates to legal drafting and the law-making process, with some Perda imposing unnecessarily complex bureaucratic processes and meeting no apparent regulatory need; and others being unworkably unclear, inconsistent with laws enacted by other tiers of government, and preceded by no public consultation. ${ }^{85}$

As discussed at the outset, all post-Soeharto regional autonomy statutes anticipated the need to provide a check on subnational lawmaking, and therefore provided mechanisms for Perda review by the national government. These mechanisms were themselves criticized for lacking effectiveness. Many local governments were notorious for failing to both send their Perda for review and to respond to negative reviews. ${ }^{86}$

80. 'ICW: 350 Kepala Daerah Kena Korupsi, 78 Tertangkap Tangan [ICW: 350 Regional Heads Hit with Corruption, 78 Caught Red-Handed]' Tempo.co (Jakarta, 7 January 20I7) < https://nasional.tempo.co/ $\mathrm{read} / 83369 \mathrm{I} / \mathrm{icw}-35$ o-kepala-daerah-kena-korupsi-78-tertangkap-tangan > accessed I 2 July 20 I 8.

8I. In the first six years of decentralization, local governments established, between them, around one thousand new taxes and user charges (retribusi) per year. See Blane D Lewis and Bambang Suharnoko Sjahrir, 'Local Tax Effects on the Business Climate' in Neil McCulloch (ed), Rural Investment Climate in Indonesia (ISEAS 2009) 224, $23 \mathrm{I}$.

82. Pratikno, 'Exercising Freedom: Local Autonomy and Democracy in Indonesia, I999-200I' in Maribeth Erb, Priyambudi Sulistiyanto and Caroline Faucher (eds), Regionalism in Post-Suharto Indonesia (RoutledgeCurzon 2005) 20; Ilyas Saad, 'Implementasi Otonomi Daerah Sudah Mengarah Pada Penciptaan Distorsi dan High Cost Economy [The Implementation of Regional Autonomy Already Leads to Distortion and a High Cost Economy]' in Decentralization, Regulatory Reform, and the Business Climate (US Agency for International Development Partnership for Economic Growth Conference, Jakarta, I2 August 2003); Bambang Brodjonegoro, 'Fiscal Decentralization and Its Impact on Regional Economic Development and Fiscal Sustainability' in Coen JG Holtzappel and Martin Ramstedt (eds), Decentralization and Regional Autonomy in Indonesia: Implementation and Challenges (ISEAS-IIAS 2009) I96; Agus Maryono, 'Thousands of Bylaws Halt Investment: BKPM', Jakarta Post (Jakarta, 26 October 2009).

83. Sukron Kamil and Chaider S Bamualim (eds), Syariah Islam dan HAM: Dampak Perda Syariah terhadap Kebebasan Sipil, Hak-Hak Perempuan, dan Non-Muslim [Shariah and Human Rights: The Impact of Shariah Bylaws on Civil Liberties, Women's Rights, and Non-Muslims] (Center for the Study of Religion and Culture 2007).

84. 'Komnas Perempuan Finds 42I Discriminatory Policies' Tempo.co (Jakarta, I9 August 2016) < https:// en.tempo.co/read/news/20I6/08/I 9/055797I 56/Komnas-Perempuan-Finds-42I-Discriminatory-

Policies $>$ accessed I 2 July 20 I 8.

85. David Ray, 'Decentralization, Regulatory Reform, and the Business Climate' in Coen JG Holtzappel and Martin Ramstedt (eds), (n 82) I 50.

86. Kementerian Hukum dan Hak Asasi Manusia Republik Indonesia [Ministry of Justice], Direktorat Jenderal Peraturan Perundang-undangan [Directorate General of Legislation], and Direktorat Fasilitasi Perancangan Peraturan Daerah [Directorate for the Facility of Perda Drafting], Panduan Praktis Memahami Perancangan Peraturan Daerah [A Practical Guide to Understanding Regional Regulation 
Another significant problem was that the Minister and governors lacked the human resources to review the many thousands of Perda issued and sent to them each year. Some Perda, therefore, simply slipped through the review process altogether, and the national government did not know of their existence until controversy about them attracted media attention. ${ }^{87}$ Even though required by law to receive and review Perda made by city and county governments, many provincial governments never established review teams or were very slow to review. ${ }^{88}$ And, even when the central government conducted reviews, they were criticized for invalidating only Perda that sought to raise revenue. Laws regulating other subject matters escaped invalidation, or even review, despite arguably contradicting central government laws or the public interest. ${ }^{89}$ For example, the national government did not move against Perda that discriminated based on gender, even though this clearly violates 'higher laws'. ${ }^{\circ}$ Although the national government never explained this focus, commentators have speculated that it helped guard central government revenue flows. ${ }^{9 \mathrm{I}}$ Another explanation is that the central government is reluctant to cancel Perda relating to religion or morality, perhaps fearing strong reactions by religious conservatives..$^{92}$

Nevertheless, the central government culled several thousand Perda during the decade preceding the Perda Review cases. One cull, part of deregulation reform that commenced in 2015 , resulted in the national government invalidating $3, \mathrm{I} 43$ laws. ${ }^{93}$ Their invalidation was part of a drive, apparently pushed by President Widodo himself, to improve Indonesia's investment climate. ${ }^{94}$ In particular, Widodo pointed to the

Design] (5th edn, Direktorat Jenderal Peraturan Perundang-Undangan 20I I); 'Banyak Perda Abaikan Kaidah yang Berlaku [Many Regulations Disregard Applicable Norms]' (Hukumonline I6 March 20I2) < www.hukumonline.com/berita/baca/lt4f62foe 755 b 5 5/banyak-perda-abaikan-kaidah-yangberlaku > accessed I 2 July 2017.

87. David Ray, 'Decentralization, Regulatory Reform, and the Business (US Agency for International Development Partnership for Economic Growth Conference, Jakarta, I 2 August 2003) I 8.

88. Butt and Parsons (n 48).

89. Simon Butt, 'Regional Autonomy and Legal Disorder: The Proliferation of Local Laws in Indonesia' (2010) 32(2) Sydney Law Review I77.

90. Law No 39 of 1999 on Human Rights, arts I(3) and $3(3)$.

9I. Butt, 'Regional Autonomy and Legal Disorder' (n 89).

92. Ihsanuddin, 'Mendagri Tegaskan Tak Ada Perda Bernuansa Islam yang Dibatalkan [Home Affairs Minister Affirms No Islamic Perda Invalidated]' Kompas (Jakarta, I6 June 20I6) < http://nasional. kompas.com/read/20I6/06/I6/I426470I/mendagri.tegaskan.tak.ada.perda.bernuansa.islam.yang.diba talkan $>$ accessed I 2 July 20 I 8.

93. Of these, I,765 were by-laws or executive orders invalidated or revised by the Ministry; and I,267 were by-laws made by county or city administrations invalidated or revised by provincial governors. Included, too, were I I I Ministerial regulations or decisions: Fajar W Hermawan, 'Daftar Perda Bermasalah Yang Dibatalkan Pemerintah [List of Problematic Perda that the Government Has Invalidated]' (Beritagar.id, 22 June 20I6) < https://beritagar.id/artikel/berita/daftar-perda-bermasalah-yang-dibatalkanpemerintah $>$ accessed I 2 July 2018. See Prima Wirayani, Grace D Amianti and Haeril Halim, 'Red Tape “Wardens” Legally Win' Jakarta Post (Jakarta, 7 April 20I7) < www.thejakartapost.com/news/ 2017/04/07/red-tape-wardens-legally-win.html > accessed I2 July 20I8; Sara Schonhardt, 'Indonesia Aims to Cut Red Tape-and Investor Skepticism' Wall Street Journal (New York, 7 January 20I6) <www.wsj.com/articles/indonesia-aims-to-cut-red-tapeand-investor-skepticismI 452 I 449 I I $>$ accessed I 2 July 20 I 8.

94. As an example of unnecessary red tape, Widodo used the establishment of a power plant, which requires 59 permits and takes between 2-6 years. He claims, during his presidency, to have reduced this to 22 permits and 220 days: 'Ada 42.00o Peraturan Menghambat, Presiden Minta Daerah Ikuti Standar Pusat [There are 42,000 Impeding Regulations, the President Asks the Regions to Follow Central Standards]' 
World Bank's annual 'Ease of Doing Business' rankings, on which Indonesia was performing poorly. ${ }^{95}$ In his view, the invalidated by-laws had made Indonesia less competitive than its neighbours in attracting foreign investment. ${ }^{96}$

Widodo emphasized that economic factors were not the only reasons for the regulatory cull. Another was strengthening tolerance and unity amidst Indonesia's plural society. He said: 'With tolerance and unity, we will become stronger in facing the future challenges of the nation.' ${ }^{97}$ This statement appears to be an indirect reference to controversial Perda that either seek to incorporate norms of Islamic law, or appear strongly influenced by them. While Islam-inspired Perda are certainly nothing new, ${ }^{98}$ Widodo's statement may have been prompted by a Perda issued by the Serang city government in $2010,{ }^{99}$ which sought to prohibit various immoral activities - referred to as 'sicknesses' in the Perda itself - in the region. ${ }^{\text {IOO }}$ Under this Perda, local enforcement officials had raided a restaurant in Serang after it had allegedly opened during the fasting month of Ramadan. ${ }^{\text {IOI }}$ This occurred only a few months before the cull and caused significant controversy, as claims emerged that local authorities had abused their authority and acted capriciously by assaulting staff and confiscating food.

Widodo also hinted that the invalidations were important for national unity. He said that, in the face of increasing challenges to the nation, the central and subnational governments needed to become an indivisible whole, with the same mission and direction. ${ }^{\text {I02 }}$ Presumably, Widodo feared that subnational governments were using Perda to pursue objectives not shared by the national government or other subnational governments. This interpretation seems to be consistent with Widodo's statements,

(Hukumonline, 9 April 20I6)<http://www.hukumonline.com/berita/baca/lt5708boe297a76/ada42000-peraturan-menghambat-presiden-minta-daerah-ikuti-standar-pusat > accessed I 2 July 20 I 8.

95. Indonesia's rank in 2016 was I09; Jokowi aimed to improve this to 4 oth: ' 2 Tahun Jokowi-JK, 3.I 43 Perda Dihapus dan i I I Permendagri Dibatalkan [2 Years Jokowi-JK, 3,I43 Perda Removed and I I I Ministerial Decisions Invalidated]' (Hukumonline, 27 October 20I6) < www.hukumonline.com/berita/ baca/lt 58 I Idd 7 a 875 b3/2-tahun-jokowi-jk-3 I 43-perda-dihapus-dan-I I I-permendagridibatalkan $>$ accessed I 2 July 2018.

96. '3.I43 Perda Bermasalah Dibatalkan, Ini Penjelasan Presiden [3, I 43 Perda Issues Invalidated, Here is the President's Explanation]' (Hukumonline, I3 June 20I6) < www.hukumonline.com/berita/baca/ lt 575 ea I 862ao89/3 I 43-perda-bermasalah-dibatalkan-ini-penjelasan-presiden > accessed I 2 July 20 I 8. Of course, these rankings refer only to the competitiveness of Indonesia as a nation, not of its subnational parts. While national officials might feel the need to respond to such rankings, subnational governments are less likely to, particularly if other subnational governments do not.

97. ibid.

98. See Robin Bush, 'Regional Sharia Regulations in Indonesia: Anomaly or Symptom?' in Greg Fealy and Sally White (eds), Expressing Islam: Religious Life and Politics in Indonesia (ISEAS 2008) I74; Michael Buehler, 'Whodunit? Politicians Affiliated with Secular Parties Implement Most Syariah Regulations' (20II) I2(I) Tempo 58, 58-59.

99. Serang Perda No 2 of 2010 on the Prevention, Eradication and Handling of Community Sicknesses.

Iоo. 'Begini Isi Perda Terkait Insiden Razia Rumah Makan di Serang [Here is the Substance of the Perda Related to Raids on Restaurant in Serang]' (Hukumonline, I3 June 2016) < www.hukumonline.com/ berita/baca/lt575e7cbbeffa7/begini-isi-perda-terkait-insiden-razia-rumah-makan-di-serang $>$ accessed I 2 July 2018.

IоI. 'Insiden Razia Rumah Makan, Ini Komentar Tiga Menteri [Restaurant Raids Incident, these are the Comments from Three Ministers]' (Hukumonline, I3 June 2016) < www.hukumonline.com/berita/baca/ lt575e65c79a Ifd/insiden-razia-rumah-makan-ini-komentar-tiga-menteri > accessed I 2 July 20 I 8.

I02. '3.I43 Perda Bermasalah Dibatalkan, Ini Penjelasan Presiden' (n 96). 
made earlier in 20I6, urging regional governments to change their laws to 'follow national standards'. ${ }^{\text {103 }}$

Despite this rhetoric, only Perda that imposed fees or charges were invalidated during this cull. This is clear from the list of invalidated Perda released by the Ministry. ${ }^{\text {IO4 }}$ Of them, I,I 35 imposed a user charge; 425 raised a tax; 60I regulated permits that required payments; and I 59 imposed fees for government administrative services, such as printing identity cards. ${ }^{\text {I05 }}$ While 548 concerned management of regional government assets, and several dozen sought to regulate various industries (such as plantations and irrigation), these, too, appeared to have revenue raising as their primary purpose. This emphasis is wholly consistent with previous Perda invalidations, which, as mentioned, focused almost entirely on revenue-raising Perda. ${ }^{\text {I06 }}$ Before the Perda Review cases, the central government had announced plans to continue culling problematic Perda. Indonesia's National Development Planning Board, Bappenas, ${ }^{107}$ had estimated that around 25,000 Perda remained in need of review, ${ }^{\mathrm{IO}}$ and the Ministry of Home Affairs had set ambitious monthly review and invalidation targets. ${ }^{\text {Io9 }}$

In summary, the bureaucratic review mechanisms that the Constitutional Court invalidated were deeply flawed. In particular, the focus of the reviews was apparently

I03. 'Ada 42.000 Peraturan Menghambat, Presiden Minta Daerah Ikuti Standar Pusat' (n 94).

I04. See Kementerian Dalam Negeri, Republik Indonesia [Ministry of Home Affairs, Republic of Indonesia], 'Daftar Perda/Perkada Dan Peraturan Menteri Dalam Negeri Yang Dibatalkan/Revisi [List of Invalidated/Revised Regional Regulations]' (Ministry of Home Affairs 20I6) < www.kemendagri.go.id/ media/filemanager/20I6/06/2 I/b/a/batal_perda_2I_juni_20I6.pdf $>$.

I05. These Perda were invalidated because public civil registration services, including printing KTPs, birth certificates and death certificates must, by national law, be free for those who cannot afford it: See ' 3 .I 43 Perda Bermasalah Dibatalkan, Ini Penjelasan Presiden' (n 96).

106. For eg in 2004-2009, the central government invalidated I,69I Perda, of which I,066 imposed user charges, 224 imposed taxes and I79 regulated licensing: Butt, 'Regional Autonomy and Legal Disorder' (n 89); Butt and Parsons (n 48). In 2009 alone, the central government invalidated 830 Perda, all of which raised revenue: Nur Sholikin, 'Efektivitas Executive Review Perda [Effectiveness of Executive Review of Perda]' (Hukumonline, 6 June 2016) < www.hukumonline.com/berita/baca/lt 5755 oe 5 c2ado $4 /$ efektivitas-executive-review-perda-broleh-nur-sholikin->accessed I 2 July 20I8. In 20I0, 407 Perda were invalidated; and in 201 2, 824 underwent the 'klarifikasi' process, whereby the central government required regional governments to amend their Perda to avoid invalidation: Nina Susilo, 'Ratusan Perda Hambat Investasi, Pemda Terlalu "Kreatif" Dan Kurang Komunikasi [Hundreds of Bylaws Hamper Investment, Local Governments Too "Creative" and Lack Communication]' Kompas (Jakarta, 2I April 20I6) < http://nasional.kompas.com/read/20 I6/04/2 I/I I 3 I09 I I/Ratusan.Perda.Hambat.Investasi.

Pemda.Terlalu.Kreatif.dan.Kurang.Komunikasi > accessed I 2 July 20 I 8.

107. Badan Perencanaan Pembangunan Nasional.

I08. 'MK Tegaskan Mendagri Masih Boleh Batalkan Perda Provinsi [Constitutional Court Confirms Home Affairs Minister Can Still Invalidate Provincial Regulations]' (Hukumonline, ro April 20I7) <www. hukumonline.com/berita/baca/lt $58 \mathrm{eb}_{3} \mathrm{eaf}_{5} \mathrm{Idd}_{2} / \mathrm{mk}$-tegaskan-mendagri-masih-boleh-batalkan-perdaprovinsi $>$ accessed I 2 July 2018.

I09. Sri Lestari, 'Mendagri Targetkan Hapus I.000 Perda Bermasalah Per Bulan [Minister of Home Affairs Target Removal of rooo Problematic Bylaws per Month]' Kompas (Jakarta, I 2 April 2016) < http:// regional.kompas.com/read/20I6/04/I 2/2020004 I/Mendagri.Targetkan.Hapus. I.ooo.Perda.Bermasala h.Per.Bulan $>$ accessed I 2 July 20 I 8 . Note, however, that estimates on the number of problematic Perda requiring review vary widely. For example, the Director General for Regional Autonomy at the Home Affairs Ministry told the media that at least 600 problematic Perda remained on the books and required invalidation: Rakhmat Nur Hakim, 'Kemendagri Akan Perketat Kontrol Pembahasan Perda [Kemendagri will Tighten the Deliberations on Regional Regulations]' Kompas (Jakarta, Io April 20 I $_{\text {) }}$ < http://nasional.kompas.com/read/20I7/04/IO/I423I38I/kemendagri.akan.perketat.kontrol. pembahasan.perda $>$ accessed I 2 July 2018. 
to protect central government interests, rather than to protect citizens from subnational governments who were predatory or sought to derive political advantage by pandering to religious conservatives. However, having some form of check on government power - however narrow - is arguably better than nothing, especially if it brings even minor economic benefits. ${ }^{\text {IIO }}$

\section{B. Relying on the Supreme Court}

The second main consequence of the Constitutional Court's decision in the Perda Review cases is that it exclusively entrusts the review of Perda to the Supreme Court. Unfortunately, this is problematic for two main reasons. The first has to do with the inherent nature of judicial review and how the Indonesian Supreme Court's judicial review jurisdiction is defined. These do not support the exercise of a predictable process of the scale that executive review has achieved. This is important because the Constitutional Court appeared to assume that the Supreme Court's taking over of the executive review function would be 'replacing like with like', and it did not consider any differences between executive and judicial review processes. The second reason is that the standard of the Supreme Court's decision-making in the reviews of Perda it performed before the Perda Review decisions, was, overall, very low. The quality of the Supreme Court's reasoning in most of these reviews is far below even the Constitutional Court's in the Perda Review cases, as problematic as it was.

\section{Inherent nature of judicial review}

Like most courts the world over, the Indonesian Supreme Court must wait for applicants to bring cases; it cannot proactively investigate legally suspect Perda on its own initiative. An economically or socially egregious Perda would therefore remain on the books unless a citizen or organization brings a challenge, which is likely to be complicated, time-consuming, and expensive. Also, the Court would hear most Perda challenges 'one by one', using a process optimistically estimated to take at least three months for each review. ${ }^{\text {II }}$ Applicants wishing to challenge a cluster of Perda will likely need to bring separate applications, with the Supreme Court unlikely to hear them together. ${ }^{\mathrm{II} 2}$

\footnotetext{
I Iо. To my knowledge, no empirical research has been conducted into whether these Perda invalidations have, in fact, improved the investment climate. Despite extensive searching, I have not discovered any reports of complaints about the invalidation of Perda. The available media reports generally contain complaints about Perda that have not been invalidated.

III. Fachri Fachrudin, 'MA Siap Terima Dampak Putusan MK terkait Pembatalan Perda [MA Ready to Accept the Impact of the Constitutional Court Decisions related to Cancellation of Perda ]' Kompas (Jakarta, I5 June 20I7) < http://nasional.kompas.com/read/20I7/06/I5/I5280I9I/ma.siap.terima. dampak.putusan.mk.terkait.pembatalan.perda > accessed I 2 July 20 I 8.

I I2. Challenging several Perda in a single case was attempted, unsuccessfully, in 20I4 and 20I 5: Supreme Court of Indonesia, Decision No 5 I P/HUM/20I 4 (delivered on 7 January 20I 5 ); and Supreme Court of Indonesia, Decision No $05 \mathrm{P} / \mathrm{HUM} / 2015$ (delivered on $30 \mathrm{March} 20 \mathrm{I} 5$ ). Of course, there are good reasons for the Supreme Court refusing to do this: Perda will generally be significantly different from each other, so might not be amenable to a joint hearing.
} 
The Supreme Court cannot, therefore, perform sweeping reviews and invalidations of several thousand Perda, as has the Ministry of Home Affairs. It is simply not designed to hear reviews against the laws issued by Indonesia's over rooo subnational lawmakers. In any event, the Supreme Court is already swamped with cases, including other judicial review applications, and it has always had difficulties keeping up with its caseload. $^{\text {II } 3}$

These impediments were highlighted by various government officials soon after the Constitutional Court's decisions were issued. The Ministry of Home Affairs announced that it was 'very unconvinced' that the Supreme Court could invalidate many Perda quickly because it could only invalidate one by one. ${ }^{\mathrm{I}}{ }^{4} \mathrm{And}$, according to one estimate, in 2000-2016, the Supreme Court heard fewer than fifty Perda reviews. ${ }^{\text {I } 5}$ Supreme Court Perda review case filings will undoubtedly increase because of the Constitutional Court's decisions. But, even if they double or triple, the Supreme Court will take decades, if not longer, to review and invalidate the number of Perda assessed by the Ministry in 2016 alone.

\section{Uncertainty about judicial review grounds}

In addition to these inherent limitations, there are legal questions about the precise scope of the Supreme Court's judicial review powers in general and in Perda Review cases in particular. As discussed in Part III, it is unclear whether the Supreme Court has the power to review any law below statutes against any other lower law, or whether it is confined to reviewing lower laws against statutes.

Debate has also centred on whether the Supreme Court's review grounds are the same as had been available to the Ministry of Home Affairs and governors. As mentioned, before the Perda Review cases, the Ministry of Home Affairs could review all types of Perda for compliance not only with higher-level laws, but also the public interest and morality. ${ }^{\text {II } 6}$ The question is whether the Supreme Court is, in effect, confined by its ordinary judicial review jurisdiction (as unclear as that is), or whether it can also consider the public interest and morality. Some scholars argue that the Court is so confined. Others, including the majority in the City/County Perda Review case, point to the 20I4 Regional Government Law and the 20I I Lawmaking Law, which require generally that Perda do not contravene the public interest or morality. They

I I3. The Supreme Court has received between IO-I 5, O00 new cases on average each year for the past decade: Mahkamah Agung [The Supreme Court], Laporan Tabunan 2016 [Annual Report 20I6] (Mahkamah Agung 20I7) 24.

I 4. 'Putusan MK Berdampak Pada Program Deregulasi Sektor Investasi [The Constitutional Court's Decision Affects Investment Deregulation Program]' (Hukumonline, 6 April 20I7) < www.hukumonline. $\mathrm{com} /$ berita/baca/lt58e6rb84aadce/putusan-mk-berdampak-pada-program-deregulasi-sekt orinvestasi $>$ accessed I 2 July 2018.

I 5. Muhammad Amin Putra, 'Masalah Pembatalan Perda oleh Mahkamah Konstitusi [Problems of Invalidation of Bylaws by the Constitutional Court]' (Hukumonline, 24 April 20I7)<www.

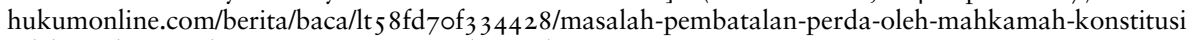
-oleh-muhammad-amin-putra $>$ accessed I 2 July 20 I 8.

I 16. It bears noting, however, that executive reviews rarely, if ever, employed public interest or morality grounds as a basis for invalidation of any type of Perda: Butt, 'Regional Autonomy and Legal Disorder' ( $\mathrm{n}$ 89); Butt and Parsons (n 48). 
argue that these statutes import the 'public interest' and 'morality' criteria for judicial review of Perda because they are imposed by statute and the Supreme Court's review jurisdiction involves ensuring that Perda comply with statutes. ${ }^{117}$ These arguments have not, to my knowledge, been tested in any review case heard by the Supreme Court, which has, in several cases, decided that it is not strictly bound by Constitutional Court decisions in any event. ${ }^{\text {II } 8}$

\section{How the Supreme Court has exercised its functions}

Quite apart from the inherent nature of judicial review and questions over the scope of the Supreme Court's jurisdiction, the Supreme Court's decisions in some judicial review cases have been highly questionable, raising further questions about the prudence of the Constitutional Court encumbering it with greater review responsibilities. As I have demonstrated elsewhere, the Supreme Court's decisionmaking over the past decade in the Perda Review cases in particular has been deeply flawed. ${ }^{\text {I9 }}$ Most of its decisions have very scant reasoning, contained in only two or three paragraphs, and some contain no legal reasoning. Many of its judgments appear to indicate a reluctance to perform judicial review at all. For example, it has restrictively applied its standing rules and refused to hear cases on technicalities, particularly when those cases raise sensitive political or difficult legal issues.

The Supreme Court has also appeared to show undue deference to government in many cases brought by citizens or private organizations. These practices stand in stark contrast to those of the Constitutional Court, which has deliberately sought to relax standing requirements and has given the impression of staunch independence from government. ${ }^{\mathrm{I} 20}$ Generally, though, the main flaw in the Supreme Court's decisionmaking is inconsistency, including, as mentioned, about fundamental issues such as whether its jurisdiction extends to review decisions (as opposed to only regulations), and lower-level laws against statutes (as opposed to also other lower-level laws). To these criticisms must be added the Supreme Court's reputation for having high levels of corruption. ${ }^{\text {I2I }}$ Of course, as mentioned, if Supreme Court review outcomes can be 'bought', either by applicants or even local governments, then the Court is hardly providing objective 'third party' review, as the Constitutional Court suggested it would in the City/County Perda Review case.

\section{INCOMPLETENESS}

Unfortunately, the City/County Perda Review case was not only poorly reasoned, lacking a clear majority, and disregarding of its consequences; the decision was also arguably incomplete, meaning that the central government might be able to avoid the

\footnotetext{
I I7. Interview with an Indonesian constitutional law academic (Jember, I I November 20I7).

I I 8. Simon Butt, “"Unlawfulness” and Corruption under Indonesian Law' (2009) 45(2) Bulletin of Indonesian Economic Studies I79.

I I9. Butt, 'Regional Autonomy and Legal Disorder' (n 89).

I 20. See generally Simon Butt, The Constitutional Court and Democracy in Indonesia (Brill 201 5 ).

I2I. Butt and Lindsey, 'Judicial Mafia' (n I 8).
} 
effect of the decision if it so chooses (though it has not indicated that it is aware of this possibility). This is because the decision does not touch upon provisions of the $20 \mathrm{I} 4$ Regional Government Law under which central government reviews and invalidations might continue to take place. ${ }^{\mathrm{I} 22}$

More specifically, Article I7(I) grants regional governments the power to make 'policy' about matters falling within their jurisdictions. 'Policy' is defined, in the Elucidation to Article I7(I), as 'Perda', and regional head regulations and decisions. However, Article I6(I) restricts this policy-making power, authorizing the central government to set norms and standards for, and to develop and monitor the implementation of, all affairs over which the central and subnational governments hold 'concurrent' jurisdiction. These norms, standards, procedures, and criteria are established by laws issued by the central government (Article I6(2)), and subnational governments must follow them (Article $\mathrm{I} 7(2))$. The central government can invalidate any non-compliant subnational policy (Article $\mathrm{I} 7(3))$.

Together, Articles I 6 and 17 establish a legal basis for the executive invalidation of Perda that resembles the provisions that the Constitutional Court struck down - they allow the central government to establish legal norms and to invalidate local laws that do not comply with them. One difference is that Articles I6 and I7 do not establish morality and public order as bases for invalidation. However, these hardly restrict the central government from performing executive review in precisely the same way it has for over a decade, given that it has very rarely, if ever, invalidated Perda on morality or public order grounds. Another difference is that the provisions establish no review procedures. This arguably gives the central government broader flexibility to perform reviews and invalidations using whatever procedures it deems necessary.

What makes the majority's failure to invalidate Article I 7 - or at least to 'amend' ${ }^{23}$ it to remove the central government's power to invalidate policy-containing Perdaeven more startling is that the applicants had expressly asked the Court to invalidate it, along with the provisions that the Court did invalidate. The majority expressly rejected the arguments based on Article I 7 without giving reasons. ${ }^{\text {I } 24}$

Neither the applicants nor the Court raised other provisions in the 2014 Regional Government Law relating to executive review, which therefore remain in law. These include provisions covering the powers of governors as 'representatives of the central government'. When acting in this capacity, governors can 'supervise county/city Perda' (Article 9I(2)(e)) and 'invalidate county/city Perda and regency/mayor regulations' (Article 9I $(3)(a))$. The Court also did not disturb Article 252, which imposes various sanctions upon local governments that continue to apply a Perda that the Minister or a governor has invalidated. These sanctions include withholding payments to parliamentarians and regional heads (Article 252(3)) and to local governments that

\footnotetext{
I22. Muhammad Amin Putra (n I I 5).

I23. On the propensity of the Constitutional Court to amend provisions, rather than simply invalidate provisions, through issuing 'conditional' decisions, see Butt, The Constitutional Court and Democracy in Indonesia (n I20).

I24. City/County Perda Review case (n 5) 2 I 2.
} 
continue to apply an invalidated Perda imposing a tax or user charge (Article 252(5)). Although Article 252(I) refers to these sanctions in connection with violations of Article 25I (subsections of which the majority did invalidate), there seems no reason why they cannot be applied to violations of Articles I6, I7, or 9I. If the majority truly intended that the central government no longer exercises review powers, it could have invalidated Article 252 on grounds of redundancy. After all, in the City/County Perda Review case itself, and in other cases, the Court has invalidated provisions that its decisions have made redundant, even though the applicants did not ask it to. ${ }^{\text {I25 }}$

\section{CONCLUSION: TOWARDS MORE COLLABORATIVE LAWMAKING?}

While the Constitutional Court's decisions in the Perda Review cases are questionable for many reasons, and have created significant confusion, they could have a positive effect, even if the government decides not to continue executive reviews on the grounds mentioned in Part VI. The national government has long been criticized for providing insufficient support to and supervision of local lawmakers, many of whom remain inexperienced. ${ }^{\mathrm{I} 26}$ Some commentators have suggested that the Constitutional Court decisions might encourage greater collaboration between national and subnational governments to set the content of a Perda before it is enacted, which might avoid the need for judicial review. ${ }^{127}$ Indeed, the Minister of Justice has suggested that problematic Perda are the result of local officials from the Ministry not being involved at the time of drafting. ${ }^{\mathrm{I} 28}$ Greater central government involvement at the drafting stage would also keep any disagreements 'behind closed doors' and encourage their resolution before enactment, rather than through public, and potentially embarrassing, post-enactment invalidation by the Supreme Court.

The main impediment to this is central government paternalism. Indeed, in response to the Constitutional Court's decisions, the Director General for Regional Autonomy at the Ministry of Home Affairs said that the Ministry was considering how it might assert more control over the Perda-enactment process, including by increasing

I25. As mentioned, the Court invalidated art $25 \mathrm{I}(8)$ of the $20 \mathrm{I} 4$ Regional Government Law, because it had 'lost its relevance' with the majority's invalidation of other parts of art 25 I: City/County Perda Review case (n 5) 206-207.

I26. Nur Sholikin (n I06).

I27. Fachri Fachrudin, 'Soal Pembatalan Perda, Mendagri Disarankan Jalin Komunikasi dengan Kepala Daerah [About the Cancellation of Local Regulations, the Minister of Home Affairs Should Establish Communication with District Heads]' Kompas (Jakarta, I7 June 20I7) < http://nasional.kompas.com/ $\mathrm{read} / 2017 / 06 / \mathrm{I} 7 / 2019254 \mathrm{I} / \mathrm{soal}$.pembatalan.perda.mendagri.disarankan.jalin.komunikasi.dengan.kep ala.daerah $>$ accessed I 2 July 20 I 8.

I28. Kristian Erdianto, 'Yasona Sebut Tiga Ribu Perda Bermasalah karena Banyak Pemda Tak Libatkan Kemenkumham [Yasona Says there are Three Thousand Problematic Perda because Many Local Governments Do Not Involve Kemenkumham]' Kompas (Jakarta, 25 June 20I6)<http://nasional. kompas.com/read/20I6/06/25/0330009I/Yasona.Sebut.Tiga.Ribu.Perda.Bermasalah.karena.Banyak.Pe mda.Tak.Libatkan.Kemenkumham > accessed I 2 July 20I 8. The Directorate General of Law and Human Rights reviewing almost 500 city and county Perda across Indonesia issued during 2005-2010 and reported that most failed to employ adequate legal drafting techniques: Panduan Praktis Memahami Perancangan Peraturan Daerah (n 86). 
supervision and imposing standard operating procedures. ${ }^{\text {I29 }} \mathrm{He}$ also mentioned 'number registration', which refers to the requirement, imposed in the 2014 Regional Government Law, for city/county governments to send their Perda to their provincial governors, and provincial governments to send their Perda to the national government, to obtain a registration number. ${ }^{130}$ Without this number, these subnational laws cannot be included in the subnational state gazette for promulgation (Article 243(I)), which is a prerequisite to the formal validity of the Perda. Using this process, the national government and provincial governors can, at least in theory, exercise control over the content of draft Perda. They can simply refuse to provide a number until the Perda is changed in line with the central government's wishes. If the national government applies these controls heavy-handedly, it is likely to draw significant resistance from local governments, thereby scuppering opportunities for collaboration.

There have long been calls for the Constitutional Court to take charge of all judicial review cases, not just constitutional review cases. The Perda Review cases have intensified these calls. ${ }^{\text {I3 }}$ These suggestions are based on the general view that the Constitutional Court's decision-making standards are far superior than the Supreme Court's. However, the Perda Review cases suggest that these views about the superiority of the Constitutional Court's performance might need revision. It may be that the Constitutional Court's reasoning has been on steady decline, heading towards the relatively low standards of decision-making and integrity of the Supreme Court. Whether the Constitutional Court can restore its once clean image and reputation for providing superior reasoning than other Indonesian courts remains to be seen. Issuing decisions less legally questionable than those discussed in this article is a necessary precondition.

\footnotetext{
I29. Nur Sholikin (n I06).

I30. ibid.

I3 I. Andi Saputra, 'Timbulkan Konflik, Seluruh Uji Materi Peraturan Harusnya di Bawah MK [Sparking Conflict, All Review of Regulations Must Be Under the Constitutional Court] Detik.com (Jakarta, I 4 November 20I7) < https://news.detik.com/berita/3727I39/timbulkan-konflik-seluruh-uji-materiperaturan-harusnya-di-bawah-mk $>$ accessed I 2 July 20 I 8.
} 